American Journal of Qualitative Research

June 2020, Vol.4 No. 1, pp. 1-15

https://doi.org/10.29333/ajqr/7841

(C) 2020 AJQR. http://www.ajqr.org
AMERICAN

JOURNAL OF QUALTATIVE

RESEARCH

ISSN: $2576-2141$

\title{
Senses of Belonging and Identity within North American Turkish Diaspora in the post-9/11 Era
}

\author{
Mehmet F. Bastug ${ }^{1}$ \\ Lakehead University
}

\begin{abstract}
The Turkish diaspora is growing rapidly in North America. Despite the vast number of studies investigated social integration and the identity construction of Turkish immigrants in European countries, Turkish communities in the United States and Canada attracted lesser attention in the academic literature. This paper seeks to understand the identity formation and acculturation attitudes of Turks and their perceptions of rejection and acceptance from their respective societies in a post 9/11 context through interviews with Turkish opinion/community leaders living in the United States and Canada.
\end{abstract}

KEYWORDS: Acculturation, Identity Formation, Islamophobia, Turkish Diaspora, TurkishAmericans, Turkish-Canadians.

\section{Introduction}

Research shows that perceived group-based rejection has an influence on the identity formation of minorities (Kunst, Tajamal, Ulleberg, \& Sam, 2012; Matrinovic \& Verkuyten, 2012; Verkuyten \& Yildiz, 2007). Various forms of religious stigma may trigger a religious identity threat, and in order to cope with such an identity threat, stigmatized groups are more likely to decrease their identification with their host nation (Kunst et al., 2012). Verkuyten and Yildiz (2007) found that perceived group rejection was associated with decreased national identification and increased religious identification among Turkish-Dutch Muslim participants. In a similar vein, Matrinovic and Verkuyten (2012) found a positive relationship between perceived discrimination and religious identification in a sample of Turkish Muslims from Germany and the Netherlands.

Other studies have demonstrated that perceived discrimination influences acculturation orientations of minorities (Berry \& Sabatier, 2010; Te Lindert, Korzilius, Van de Vijver, Kroon, \& Arends-Tóth, 2008). Perceived discrimination is considered as one of the antecedent conditions of the acculturation process (Celenk \& Van de Vijver, 2011). Robinson (2009) argued that immigrants who perceive discrimination prefer a separation strategy rather than that of integration or assimilation. Various research studies also revealed a relationship between identity and

\footnotetext{
${ }^{1}$ Corresponding author; Dr. Bastug is a lecturer in the Department of Interdisciplinary Studies at Lakehead University. E-mail: mbastug@lakeheadu.ca
} 
acculturation orientations (Badea, Jetten, Iyer, \& Er-rafiy, 2011; Kaliska \& Akbey, 2019; Nesdale, 2002; Nesdale \& Mak, 2000; Safdar, Calvez, \& Lewis, 2012). While some studies treat national or ethnic identity as an outcome of acculturation attitudes (e.g., Nesdale, 2002; Nesdale \& Mak, 2000), others show that national or ethnic identification can predict acculturation (Badea et al., 2011; Safdar et al., 2012). Bastug and Akca (2019) investigated the effects of perceived rejection on group identification and acculturation attitudes in a sample of Turkish-Canadians and found that national identification positively predicts the endorsement of assimilation and integration, and negatively predicts the endorsement of separation.

This study examines the perceived rejection and its effects on identity formation and acculturation attitudes among Turkish immigrants in the US and Canada through interviews with Turkish opinion/community leaders. The interviews focused on three key areas: perceived rejection/Islamophobia, identity formation, and acculturation attitudes.

\section{Perceptions of Acceptance and Rejection}

As Phinney, Berry, Vedder, and Liebkind (2006) argued, immigrants typically face varying degrees of discrimination in their country of settlement. The context and the level of Islamophobia differ between Europe and North America. In Europe, where anti-immigrant sentiment transforms into Islamophobia, Muslim immigration is considered to be associated with an increase in the potential for terrorism (Cesari, 2009). According to Pew Research's 2006 survey, 20\% of British respondents, $18 \%$ of German respondents, $20 \%$ of French respondents, and $41 \%$ of Spanish respondents believe that most or many Muslims in their countries support Islamic extremists. Comparably, 19\% of Americans share the same belief. Canadians are less likely to support this belief according to the Environics Research Group 2006 survey. Only 13\% of Canadians respondents believe that most or many Canadian Muslims support Islamic extremists (Environics Research Group, 2006).

With regard to Canada, the outstanding feature of Canadian society is that immigrants comprise a large share of its population, and the percentage is increasing every year (Hanniman, 2008). Furthermore, the Muslim percentage of the Canadian population has been on the rise (Hanniman, 2008). A 2011 National Household Survey showed that the Muslim population in Canada has since increased to over one million, comprising 3\% of the total population (NHS 2011).

The 9/11 attacks led to a backlash and resulted in significant consequences for Muslims in Canada (Hanniman, 2008), just as it did in the United States. Law-abiding Muslims in the West are anxious about the increase in anti-Muslim sentiments (Smith, 2009). Many Muslim-Americans identify prejudice against Islam as the main problem they face while living in the United States (Smith, 2009). On the other hand, Environics Institute's survey on Canadian Muslims (Environics Research Group, 2006) showed that $77 \%$ of Canadian Muslims believe that the treatment of Muslims in Canada is better than other Western countries. Similarly, the Macdonald-Laurier Institute's 2011 survey revealed that $71 \%$ of Muslim-Canadians report satisfaction with Canada (Leuprecht \& Winn, 2011), whereas Pew Research's Muslim-Americans survey (Pew Research Center, 2007) showed that 38\% of Muslim-Americans reported satisfaction with the United States. A high proportion of Canadian Muslims sees hostility toward them as being marginal in their host society (Pew Research Center, 2007).

Several models in the literature (see Brancombe, Schmitt, \& Harvey, 1999; JasinskajaLahti, Liebkind, \& Solheim, 2009) indicate that perceived rejection from host society increases ingroup identification and decreases national out-group identification. Furthermore, perceived discrimination is shown to affect immigrants' acculturation attitudes. Berry, Phinney, Sam, and 
Vedder (2006) researched immigrant youth's identity formation and acculturation attitudes in 13 countries. They found that perceived discrimination is negatively related to participants' involvement in broader society, as it is significantly associated with attitudes towards separation and marginalization.

\section{Turkish Immigrants in the United States and Canada}

According to the U.S. Census Bureau 2017 American Community Survey, it is estimated that 222,593 people with Turkish origin live in the US. Three major waves of Turkish immigration to the United States are identified in the literature (Karpat, 2006; Kaya, 2004). The first wave of immigrants came to the United States during the period between 1820 and 1920 (Kaya, 2004). The first wave of immigrants included not only ethnic Turks but also other ethnic groups, such as Armenians and Greeks who carried Ottoman passports (Kaya, 2009). These early Turkish immigrants mostly assimilated, or they returned to Turkey after WWI, thus disappeared as an ethnic group (Karpat, 2006).

The second wave of Turkish immigrants to the United States began in the early 1950s and lasted through the 1970s (Karpat, 2006). Karpat distinguished the characteristics of second-wave immigrants from the first wave of immigrants. He argued that the second wave of immigration was "more of a 'brain drain' than a mass movement" (2006, p. 171). For him, although their total number was far below that of first wave immigrants, their impact was greater. However, because there were fewer, they could not establish communities characterized as being Turkish (Karpat, 2006).

As Kaya (2004) stated, the third wave of immigration began in the mid-1980s. After the 1990s, due to the developments in transportation and the Turkish government's policies toward openness, immigration accelerated. He further argued that the third wave of immigrants was more diverse than those came in the early waves. Whereas the second wave of immigrants identified themselves as "Westernized Turks," those who came in the third wave identified themselves as "modern Muslim Turks" (Karpat, 2006, p. 173). Unlike the first wave, they were successful in creating their own communities (Karpat, 2006).

According to Kaya (2004), Turkish-Americans tend to disassociate themselves with other Muslim groups, especially Arabs. They argue that their interpretation and practice of Islam is different from other groups, and believe that they are more modern, peaceful, and tolerant. They emphasize their Americanness and they assert that Turks had nothing to do with 9/11 events. As Kaya stated, "They are Muslim, yet they claim their differences and promote Turkishness. They are viewed as Middle Easterners, yet they assert their Europeanness as well as their Muslimness. They are seen as outsiders, yet they profess their Americanness" (2004, p. 295).

Canada is also another country of destination for Turkish immigrants. According to the 2016 census, there were 63,955 people living in Canada who claimed to have Turkish origin (Statistics Canada, 2016). As Ozcurumuez (2009) reported, Turks began to immigrate to Canada after World War II to seek better economic and educational opportunities and the first wave of immigrants from Turkey came to Canada in the period between 1960 and 1970. He added that most of them were skilled professionals and students. After the 1980s, immigration from Turkey diversified and included skilled workers, investors, asylum seekers, and those who arrived for family reunification. They settled in major cities, such as Toronto, Montreal, and Vancouver, where they could find more job opportunities.

In the last few years, we are experiencing a fourth wave of Turkish immigration to the United States and Canada as a result of political turmoil in their home countries. The increasingly 
authoritarian style of government in Turkey and state oppression of certain ethnic, religious and social groups forced thousands of Turkish citizens (including Turks, Kurds, and other ethnic groups targeted by the regime) to leave their home country. Many of those who fled to the United States and Canada applied for refugee status in their respective host countries. Recent figures show a growing number of refugee claimants from Turkey (see Immigration and Refugee Board of Canada, 2018).

\section{Current Research}

The qualitative research setting designed for this research involved semi-structured faceto-face and phone interviews with six Turkish opinion/community leaders from the United States and four from Canada, including leaders of Turkish community organizations, imams of Turkish mosques, and well-known individuals in the community. All ten participants were male. Interview questions were designed to understand participants' perceptions of Islamophobia and their conationals' identity formation and level of integration into their respective societies. This research is part of a larger research project which focuses on the relationship between perceived rejection, national and religious identification, acculturation attitudes and the likelihood of experiencing an identity crisis among Turkish immigrants to the US and Canada. The whole project collected quantitative and qualitative data in 2015 to analyze the hypothesized relationship. Partial results from the quantitative part of the research have been published previously (Bastug \& Akca, 2019). This paper reports the findings from the qualitative component of the research from a comparative perspective.

\section{Findings}

\section{Findings on Islamophobia}

This research explores the effects of perceived rejection on integration and identity formation. Interview participants were asked about their understanding and perceptions of Islamophobia, as well as their experiences with it. Based on their responses, the research attempted to provide a general overview of perceived Islamophobia among Turkish-Americans and TurkishCanadians.

The interviews revealed that perceived Islamophobia among Turkish-Americans and Turkish-Canadians is modest. Although Turkish immigrants in these countries perceive some level of Islamophobia, they do not see it as the biggest problem they face. They mostly see their respective countries as welcoming societies for Muslims. They usually mentioned the terms "misperception" and "prejudice" when defining Islamophobia. Most participants believe that a misunderstanding of Islam is the main driving factor for prejudice against Muslims. One participant (PUS-6) stressed:

Islamophobia is not based on real knowledge of Islam. It is based on what people have been taught about Islam. They have been taught that Islam is a backward and violent religion, and it mandates believers to perpetrate violence against non-believers. Fear of Islam and Muslims is built upon misinformation about or misperceptions of Islam.

When it comes to experiences of Islamophobia, participants highlighted two important 
points. The first one is about the effects of $9 / 11$ and following terrorist attacks on their lives, and the second was about the fact that women experience more Islamophobia than men. Most of them believe that $9 / 11$ only had short-term effects. Some revealed that they experienced some degree of backlash following $9 / 11$ for a short time, but after the shock of the events had passed, life returned to normal. A few participants believe that 9/11 was a turning point in relations between Muslims and the United States society, and it continues to affect their daily lives. A participant emphasized that Muslims in his community expressed that they had almost no problem before $9 / 11$, and the United States was a heaven for Muslims. They declared that they began having problems in the United States after these tragic events occurred.

Interviews revealed that the likelihood of experiencing Islamophobia depends on socioeconomic class. Interview participants that reported being in contact with upper-class Muslims expressed that they and their connections did not face severe Islamophobia or backlash right after 9/11. Lower class Muslim immigrants, on the other hand, were more likely to experience an Islamophobic event.

A participant stated that he and his wife became targets of discrimination several times after the 9/11 attacks. He said that he experienced discrimination and hate crimes especially when he was with his wife. He expressed that he cannot be identified as a Muslim by his appearance, but his wife can easily be identified because of her headscarf. Since Turkish men do not have traditional clothes like Arabs, and most do not grow a beard, it is difficult to discern whether they are Muslims. However, wearing a headscarf makes it easy to be identified as a Muslim. He reported that he suggests to his wife that she not go out on the anniversary of $9 / 11$, as she may experience an Islamophobic incident. Another participant from Canada reported that while his wife was walking outside, a Canadian woman told her that she did not have to cover her head because Canada is a free country. Furthermore, this woman told his wife that her rights could be defended if she was being forced to cover her head. This experience demonstrates the common belief among Western, non-Muslim people that Muslim women are oppressed.

A participant reported that he had a neighbor who was unemployed for a long time because he could not find a job. He said that his neighbor was jealous of him, since both he and his wife, as immigrants, had good jobs. His neighbor began calling him "nasty Pakistani," thereby insulting him without knowing his origin. On one occasion, he recorded his neighbor's verbal abuse and sued him. He obtained a restraining order from the court. He explained that the judge told his neighbor, "You are not going to look into his eyes. If he ever comes and says you looked into his eyes, I am going to put you in prison." He was very impressed after he saw that laws in the United States protect anyone and everyone that is subjected to discrimination. At that point, he understood that even though they may encounter Islamophobia in a broader society was possible, they could feel safe, as there were also laws to protect them.

Those participants who perceived a lower incidence of Islamophobia in the respective countries where they reside believed that Islamophobia is common mostly among low-educated people who learn everything from the media and do not research or read any real information about Islam and Muslims. Participant PUS-4 explained that Turkish immigrants to the United States are mostly well-educated people who have professional jobs. Hence, they are generally around other well-educated people. This explains why they do not perceive a higher degree of Islamophobia. He also said that since there are a considerable number of Muslim immigrants in the United States, especially on the East and West Coasts, Americans become more used to living around Muslims. He added that he has prayed many times at public rest areas while traveling where he can be easily seen by others. He said that neither he nor his friends have never gotten any reactions while they were praying. Another participant from Canada (PCA-1) expressed that the level of Islamophobia 
changes from place to place. He mentioned that in the cities where there is a considerable immigrant population, Muslims are less likely to face discrimination. He expressed that they could worship in public parks without any worry in Toronto, but they could not do the same in less urban areas.

Research shows that most Americans' knowledge about Islam and Muslims is substantially based on media reports (Nacos \& Torres-Reyna, 2007). Thus, the image of Islam in the minds of non-Muslims is predominantly shaped by the media. According to Nacos and Torres-Reyna (2007), the stereotypical depiction of a Muslim male as violent and female as oppressed in the American media is the principal complaint among Muslims. Their research was conducted two years after 9/11 and showed that about 77\% of American Muslims believe that the American media is unfair in their portrayal of Muslims. In a recent research study, Kerns, Betus and Lemieux (2019) examined news coverage in the U.S. local and national newspapers for all terrorist attacks in the U.S. between 2006 and 2015. They found that terrorist attacks carried out by Muslims received $357 \%$ more coverage than other terrorist attacks. The research revealed that although Muslim perpetrators were responsible for $12.5 \%$ of the attacks perpetrated within the studied period, they received $50.4 \%$ of the news coverage. According to Edward Said (1997), covering Islam in the media is a one-sided activity. Consequently, the portrayal of Muslims in the media could be quite different from reality. In a similar vein, some scholars argued that Canadian media makes the same mistake by equating Islam with terrorism (see Ismael \& Measor, 2003). Canadian Muslims also have concerns about media representations and believe that common media images of Muslims in Canada are Islamophobic and do not accurately represent Muslims (Sharify-Funk, 2009). Consequently, Canadian Muslims construct their identities defensively, contrasting to the image portrayed in the media (Sharify-Funk, 2009).

Almost all of the participants believe that media exacerbates Islamophobia. The coverage of Islam and Muslims in the Western media is the main concern about Islamophobia among the participants. They believe that the portrayal of Muslims in the media is usually negative and stereotypical and that moderate peaceful Muslims, who constitute the vast majority of all Muslims, receive too little media coverage. Some participants emphasized the media's double standard. They believe that the media is unfair when it comes to reporting about Muslims. They agree that the media is deliberately stereotyping Muslims, representing them as aggressive. A participant (PUS2) revealed his concern about the media as follows:

I think the way the media reports news about Muslims is provocative. In the news, Muslims are always associated with violence. The media does not cover positive actions taken by Muslims and Muslim organizations. All the news related to Muslims is about terrorism, violence, and conflict... The media's coverage of Muslims can be defined as provocative because it may lead people to be more aggressive towards Muslims.

There is an ongoing debate in the Muslim world about whether and, if so, how Islam should be reinterpreted to facilitate Muslims' adaptation to modern life. Zaman (2010) examined the views of modern Islamic scholars about Islam and modernity. His study revealed that many Islamic scholars believe in the necessity of bringing Islam and modernity together. Those scholars believe that learning secular sciences does not undermine Islam, and rather this is even necessary to enable Muslims to live in modern conditions (Zaman, 2010). Many participants believe that Muslims could not successfully adapt to modern life. A participant (PCA-1) suggested:

Today's Muslims try to practice Islam as it was practiced hundreds of years 
ago. Many Muslims cannot adapt to the modern world. They think that being a Muslim is only about wearing traditional clothing and growing a beard. Islam is a universal religion. It is a religion for all times, for all places. It is compatible with today's world. If Muslims want to gain acceptance in Western countries, we should adopt the modern way of life without sacrificing our religion.

Participants also highlighted ignorance as a major problem that the Muslim world faces today. Some believe that many Muslims are ignorant - even of their own religion and that is why they misrepresent Islam. Self-criticism by Muslim scholars also stresses this point. Fatoohi (2004) stated that one of the most imported reasons for the distorted image of Islam in the West is ignorance on behalf of Muslims about their own religion. According to him, the actions that some Muslims take and the ideas they adopt under the name of Islam have nothing to do with Islam. However, these misconstrued ideas and actions are unfairly associated with Islam by the Western world, which creates fertile ground for Islamophobia (Fatoohi, 2004). Educating others about "true Islam" is seen as a solution by many Muslims to deal with extremism. A participant (PUS-6) criticized the reactions of the Muslim world against a small church's plan to burn the copy of the Quran, which he believes lead to Islamophobia:

Impulsive behavior by Muslims also helps Islamophobia to persist. Sometimes Muslims react suddenly, which is very meaningless and foolish. For example, a pastor of a church here in the United States said that he was going to burn the Quran on the anniversary of the 9/11 attacks. As a reaction to this plan, many Muslims participated in violent demonstrations all over the world. Such violent behavior incites hostility among Western people. We should react wisely and prudently.

Most of the participants were well aware of the common problems and issues that Muslims have to deal with. Surprisingly, some blame Muslims more than they blame Westerners for the presence of Islamophobia. They pointed out that Muslims should handle these issues, above all to convince people that Islam is not something to fear. A participant (PCA-1) revealed:

I do not put all the blame on the Western world. Yes, they do make some mistakes, but Muslims are mainly responsible for Islamophobia. We have failed to represent Islam correctly. Western people's mistake is not to investigate the truth before accusing them. But, again...we should correct our mistakes first and increase our efforts to better represent Islam in real life.

\section{Findings on Acculturation Orientations}

The majority of interview participants believe that although integration is the preferred acculturation strategy among Turkish immigrants, they usually end up assimilating. They reported that the adoption of an attitude of marginalization was very rare. With respect to separation, they expressed that this type of acculturation orientation is common among certain groups, especially lower socioeconomic classes.

A participant expressed that most of the Turkish immigrants who came to the United States 
more than 20 years ago voluntarily assimilated into United States society. However, those who came within the last 20 years chose integration rather than assimilation. Another participant acknowledged that in some places, there are groups of Turkish immigrants who live as if they are not living in the United States, but rather in Turkey. He admitted that they are, to some extent, separated from American society and removed from U.S. politics. He further added that "They watch Turkish news; they are affected by political divisions in Turkey, and they are divided into different cliques. They can't even unite within their own small community." PUS-6 stated that acculturation attitudes depend on where one lives in the country. He noted that when a Turkish immigrant lives in a city where there are a considerable number of Turkish immigrants, he or she might separate from American society.

PCA-4 argued that education level is an important predictor for acculturation attitudes. $\mathrm{He}$ claimed that well-educated immigrants can more easily integrate into broader society compared to their less-educated counterparts. He believes that well-educated immigrants are more capable of learning a foreign language, which is important for integration. Another factor that influences acculturation attitudes is the reasons one has for immigrating. A participant (PUS-2) noted:

The motivation behind the migration of earlier Turkish immigrants to the United States was to earn money and then return to Turkey. This motivation hindered their integration into United States society because they did not come to this country to stay permanently. That is why there is no Turkish cemetery in this country. Most of the mosques are former churches, which were converted to mosques. Turkish immigrants have not even built a mosque from scratch for many years. However, after spending years in this country, most immigrants changed their minds.

A participant from Canada expressed that socioeconomic background is an important factor that affects one's acculturation orientation. He explained that less-educated immigrants from the working class could neither integrate into Canadian society nor maintain their culture of origin. On the other hand, he argued that educated immigrants from higher socioeconomic strata could choose either integration or assimilation depending on their degree of loyalty to their culture of origin. He added that those who adore and glorify the Western world assimilate readily, give Canadian names to their children, and do not teach Turkish to them. PCA-2 also argued that assimilation is inevitable for many Turkish immigrants. He claimed that those who do not have strong bonds with their culture of origin tend to assimilate.

According to PUS-5, young people belonging to the first wave of Turkish immigrants fully assimilated, whereas older people separated from American society. The second wave of immigrants tried to adapt to American society, but at the same time maintaining their culture of origin. They built mosques and established cultural organizations in order to maintain the ties between young people and the Turkish community. The third wave of Turkish immigrants was far more successful at integrating into American society without assimilating or separating. Another participant (PUS-3) emphasized the importance of maintaining the Turkish language in order to prevent full assimilation:

The first generation of immigrants kept their language, but their children preferred to speak English. The second generation could speak Turkish but did not teach Turkish to their children. Hence, Turkish, as a language, almost disappeared by the third generation. Language is important for 
staying connected to culture. As they forgot their language, they forgot their ancestors' culture too.

Saroglou and Mathijsen's (2007) study the degree of religiousness of European Muslims on their collective identities and acculturation orientations showed that greater religiousness predicted attachment to the culture of origin. Participant PUS-3 highlighted the role of religion in keeping a community together:

Religion is an important common ground for a community that helps protect the culture. There is no religious education in schools, and the youth is not interested in mosques. Kids go to mosques to attend weekend schools with their parents' encouragement. As they grow up and start secondary school, they break their bonds with the mosque. Furthermore, as they start high school, they begin loosening their bonds with their families, and finally, they completely break away from the community after going to college. We cannot seem to create an environment in which the young generation maintains their ties with the community.

According to PUS-3, mosques are not attractive to young Muslims. He believes that since mosques cannot play a significant role in increasing young Turkish-Americans' attachment to their culture of origin, the best way to achieve healthy integration and prevent assimilation is by establishing youth centers in the community. He added:

What young people want is a place where they can have fun, play sports, listen to music, and be social. They cannot do any of these things in a mosque. As a result, they go to other places to have fun. The community has expectations from Imams to teach our children our culture and Islam, and keep them away from extremism. However, Turkish Imams are government officials who come from Turkey for a specific time of service and are not familiar with the young generation in this country. The community itself tries to handle this issue by encouraging young ones to study Islam either in Turkey or in the United States, and then be assigned as Imams in the mosques, but the young people do not have any interest in this. The best way to uphold the loyalty of the young people to the community is to transform the community in a way that can address their needs. I think youth centers where they can learn their culture, traditions, and religion, but at the same time can have fun, watch movies, listen to music, and play sports, are the best alternatives to mosques in today's conditions.

PCA-3 stressed another important point. He explained that since the Muslim identity of Turkish-Canadians does not make them feel vulnerable, they do not hesitate to interact with broader society, which, in turn, facilitates and expedites assimilation. He further stated that in Europe people feel that their Muslim identity is threatened, and they feel forced to assimilate. Consequently, they develop defense mechanisms against assimilation. In Canada, Turks send their children to Canadian schools without having any concerns. They do not believe that the Canadian government or society forces them to assimilate. Because they feel their children are safe, they let 
them have more freedom. As a result, their children are more likely to assimilate. However, in Europe, the Turks are very concerned about their children. They force them to learn Turkish and to stay connected to their culture of origin. In sum, as PCA-3 articulated, when the host society forces immigrants to assimilate, they are less likely to assimilate.

Various factors can influence the acculturation orientations of immigrants. Research shows that acculturation orientations are associated with perceived discrimination (Berry \& Sabatier, 2010; Celenk \& Van de Vijver, 2011; Te Lindert et al., 2008) and self-identification (Badea et al., 2011; Nesdale, 2002; Nesdale \& Mak, 2000; Safdar, Calvez, \& Lewis, 2012). The results of the interviews suggest that perceived Islamophobia is not strongly associated with the acculturation orientations of the majority of Turkish-Americans who participated in this study. Most of the participants believe that the influence of the Islamophobia on acculturation is very limited if it has any influence at all.

On the other hand, PUS-2 believed that Islamophobia encourages assimilation. According to him, those who do not practice their religion, do not have enough knowledge about it, and/or cannot defend Islam when it is questioned usually hide their beliefs, or sometimes give up their religion. Consequently, they move away from their own culture and assimilate. But, he thought that Islamophobia also encourages integration. He claimed that perceived Islamophobia encourages the integration of those who care about their religion and want to show others that Muslims are peaceful people. He added that faithful Muslims cannot hide their religion because they feel an identity conflict when they try to do so. They choose to introduce themselves as "good Muslims" to society and want to set good examples. He shared an experience:

We organized an event at our mosque and collected donations. Then we went to an American charity organization and gave all the donations to them. They were very surprised; they did not expect to receive a donation from a mosque. My community launched this initiative in order to show that they are a part of American society and want to contribute to this society as Muslims.

PUS-4 claimed that Islamophobia did not affect Turkish immigrants' acculturation attitudes. He explained that a Turkish-American's lifestyle and style of dress are very similar to those of an American. Hence, Turkish immigrants do not feel rejected by society. PUS-5 agreed that Islamophobia had almost no effect on the integration of Turkish immigrants. He believed that they can practice their religion freely in the United State and that there are almost no obstacles to be overcome. On the other hand, PUS-6 had a different opinion. He believed Islamophobia to have a strong influence on acculturation attitudes. He said that he would be more integrated into American society and he would feel more American if 9/11 had never happened.

\section{Findings on Identity Formation}

Identifying with a group has important consequences on one's social behavior (Jackson \& Smith, 1999), including acculturation preferences (Badea et al., 2011; Safdar et al., 2012). The author asked participants about the identity formation of Turkish-Americans and TurkishCanadians and the factors that affect this formation.

A participant from the United States (PUS-1) argued that Turkish immigrants that came to the United States over 20 years ago introduce themselves with their Turkish identity. According to

him, those immigrants mostly have secular backgrounds, and they tried to avoid being known as 
Muslims. However, he added, those who immigrated to the United States in the last 20 years do not hesitate to reveal their Muslim identity. They introduce themselves as both a Turk and a Muslim. PUS-2 also confirmed that immigrants from conservative backgrounds bring their Muslim identity to the forefront, whereas those from backgrounds that are more secular primarily identify themselves as Turks rather than Muslims.

Religious conversion is very rare among Turkish immigrants. As PUS-4 stressed, it is not at all common that a Turkish-American would hide his or her Muslim identity because of shame or fear. However, he argued that some third-generation Turkish-Americans chose to renounce even their Turkish identity. He added that they completely assimilated and identified themselves as Americans. According to PUS-2, some of those immigrants report that when they are asked about their religion, they state they do not have one. However, it does not necessarily mean that US-born Turkish-Americans broke all their connections with their culture of origin.

PUS-2 also argued that, after the 9/11 attacks, Turkish Americans tried to isolate themselves from the Arab community and rather highlighted their Europeanness. He suggested that although Turks claim that Turkey is not a part of the Middle East, many Americans believe that Turkey is a Middle Eastern country. While there are various ethnic groups within the Muslim world, PUS-4 emphasized that these different ethnic groups are separated from each other in the United States. Each group has its own community and its own mosques, schools, and organizations. Each group wants to be acknowledged as having their own ethnic identity. PUS-4 argued that Turks, in general, are strongly nationalist; Turkish immigrants in the West identify themselves primarily as Turks and secondly as Muslims because they do not want to be associated with Arabs.

Most of the participants stressed that US-born Turkish-Americans usually identify themselves first as Americans and second as Turks. PUS-5 gave an example, which illustrates such identity preference:

My children were not born in the United States, but my nephews were born here. I asked my nephews which team they would support if there were a soccer match between Turkey and another country. They said they would support Turkey. Then I asked them which team they would support if the match were between Turkey and the United States. They answered that they would support the United States.

In the same vein, PCA-3 expressed that once Turkish-Canadians obtain Canadian citizenship, they start feeling more Canadian and use Canadian passports rather than their Turkish passports, even when they go on pilgrimage. Conversely, as PUS-6 emphasized, those Turks who prefer to separate themselves from American culture resist their children's inclination toward assimilation. They do not want their US-born children to say, "I am an American."

Most of the participants believe that Islamophobia does not affect the identity formation of Turkish-Americans in general. PUS-6 stated that since Muslim Americans are generally well educated, they could easily overcome the negative effects of Islamophobia. He stressed that they were organized and created advocacy networks against Islamophobia. He compared Muslims in the United States with those in Europe and said that Muslims in Europe could not organize to advocate for themselves because they were not as educated as Muslims in the United States. On the other hand, a few participants believed that Islamophobia, to some extent, has changed how people identify themselves. PUS-6 revealed:

\section{I do not feel comfortable disclosing my Muslim identity. I believed that I}


should prove myself first before telling others that I am Muslim. For instance, I have proved myself in my job. My colleagues like me and know me as a good person who helps others. Now Ifeel free to reveal my religion, and I feel free to pray when we are in the same room. However, I would not do that the first few years that I had this job because I would afraid of not getting tenure.... When my colleagues realized that I am Muslim, they began thinking that I am an exception.

A participant from Canada (PCA-1) noted that Muslim Canadians are afraid of being associated with terrorist groups. He expressed that although Canada is a multicultural society, Muslims worry about being identified as terrorists because of their appearance. On the other hand, PCA-2 thought that this concern was more related to a lack of self-confidence. He noted that if a Muslim has enough knowledge about his or her religion and feels confident, s/he could advocate on his/her own behalf and tell others about the distinction between mainstream Islam and extremist ideologies. He argued that a Muslim with confidence, indeed, has nothing to worry about and are less likely to experience an identity crisis.

Participants reported that having an identity crisis is very rare among Turkish immigrants in the United States and Canada. Some participants from the United States believe that perceiving Islamophobia may trigger an identity crisis. They provided some examples of how perceived group-based discrimination can affect the identity formation of Turkish-Americans. On the other hand, none of the participants from Canada claim that perceived Islamophobia influences the likelihood of having an identity crisis. Furthermore, they do not agree that perceived Islamophobia has any influence on the identity formation of Turkish-Canadians.

\section{Conclusion}

Interviews showed that Turkish immigrants in both the United State and Canada do not see Islamophobia as a constant threat to their wellbeing. Only a few participants believed that Muslims are still suffering from the $9 / 11$ backlash. Many others claimed that although Muslims experienced discrimination and hate crimes in the wake of 9/11, life returned to normal for Muslim immigrants after the shock of the events had passed.

Participants reported that the acculturation attitudes among Turkish immigrants have changed over time. They have concerns about the increased assimilation of Turkish youth in both countries. Interestingly, some participants reported that Muslim immigrants in North America did not develop defense mechanisms against assimilation because there has been little to no pressure on immigrants to assimilate. They believed that the lack of such pressure on immigrants led them to assimilate easily and, furthermore, believed that Turkish immigrants both in the United States and in Canada are more likely to assimilate than those in Europe, where immigrants are more pressured to assimilate. They also hold that education level and socioeconomic background are important predictors for acculturation attitudes. Regarding integration, the interviews revealed that Islamophobia did not have a considerable negative effect on integration. Some participants even reported that perceived Islamophobia encouraged the integration of some immigrants who were eager to show others that Muslims are peaceful and a part of this society. Participants expressed that emerging Islamophobia, in general, did not affect the acculturation preferences of Turkish immigrants. Opinion leaders believed that Turkish immigrants did not choose separation or marginalization as a response to Islamophobia. Conversely, they argued, many immigrants aimed at increasing their integration into the host society in order to gain acceptance. Participants stressed 
that most US-born Turkish-Americans identify themselves as Americans first and Turks second. The same was true for the Canadian-born Turkish-Canadians. The majority of the participants from both countries argued that Islamophobia did not affect the identity formation of Turkish immigrants in general.

Another important point to mention is that many Turks in North America began to identify themselves less with their ethnic background as a result of growing political tensions between Turkey and the West. Expanding human right violations and increasingly authoritarian style of governing in Turkey discourage well-integrated Turkish-Americans and Turkish-Canadians to express their Turkishness. Recent figures show that thousands of people from Turkey flow to the U.S. and Canada every year to escape from the repressive regime. Turkish diasporas in these two countries seem to be divided between supporters and opponents of the current regime in Turkey. Future studies should investigate the impact of the authoritarian and anti-Western direction of the Turkish government over the identity formation of the Turkish diaspora.

\section{Acknowledgment}

This paper is partly derived from the author's doctoral dissertation.

\section{References}

Badea, C., Jetten, J., Iyer, A., \& Er-rafiy, A. (2011). Negotiating dual identities: The impact of group-based rejection on identification and acculturation. European Journal of Social Psychology, 41(5), 586-595.

Bastug, M. F. \& Akca, D. (2019). The effects of perceived Islamophobia on group identification and acculturation attitudes. Canadian Review of Sociology 56(2), 251-273.

Berry, J. W. \& Sabatier, C. (2010). Acculturation, discrimination, and adaptation among second generation immigrant youth in Montreal and Paris. International Journal of Intercultural Relations, 34(3), 191-207.

Berry, J. W., Phinney, J. S., Sam, D. L., \& Vedder, P. (2006). Immigrant youth in cultural transition: Acculturation, identity, and adaptation across national contexts. London: Psychology Press.

Branscombe, N. R., Schmitt, M. T., \& Harvey, R. D. (1999). Perceiving pervasive discrimination among African Americans: Implications for group identification and well-being. Journal of Personality and Social Psychology, 77(1), 135-149.

Celenk, O., \& Van de Vijver, F. J. R. (2011). Assessment of acculturation: Issues and overview of measures. Online Readings in Psychology and Culture, 8(1), 1-22.

Cesari, J. (2009). Securitization of Islam in Europe. In J. Cesari (Ed.), Muslims in the West after 9/11: Religion, politics and law. London; New York: Routledge.

Environics Research Group (2006). Focus Canada. Toronto, ON: Environics Institute.

Fatoohi, L. (2004). Jihad in the Qur'an: The Truth from the Source (2nd Ed.). Birmingham, UK: A. S. Noordeen.

Hanniman, W. (2008). Canadian Muslims, Islamophobia and national security. International Journal of Law, Crime and Justice, 36, 271-285.

Immigration and Refugee Board of Canada (2018). Refugee claims statistics. https://irbcisr.gc.ca/en/statistics/protection/Pages/index.aspx

Ismael, T. Y., \& Measor, J. (2003). Racism and the North American media following 11 September: The Canadian setting. Arab Studies Quarterly, 25(1/2), 101-136. 
Jackson, J. W., \& Smith, E. R. (1999). Conceptualizing social identity: A new framework and evidence for the impact of different dimensions. Personality and Social Psychology Bulletin, 25(1), 120-135.

Jasinskaja-Lahti, I., Liebkind, K., \& Solheim, E. (2009). To identify or not to identify? National disidentification as an alternative reaction to perceived ethnic discrimination. Applied Psychology: An International Review, 58(1), 105-128.

Kaliska, L., \& Akbey, B. (2019). Post-traumatic Stress Disorder Related to Trait Emotional Intelligence of Slovaks in Comparison to Turkish Immigrants in Slovakia. Journal of Ethnic and Cultural Studies, 6(3), 147-156. http://dx.doi.org/10.29333/ejecs/283

Karpat, K. H. (2006). The Turks finally establish a community in the United States. International Journal of Turkish Studies, 12(1/2), 167-186.

Kaya, İ. (2004). Turkish-American immigration history and identity formations. Journal of Muslim Minority Affairs, 24(2), 295-308.

Kaya, I. (2009). Identity across generations: A Turkish American case study. Middle East Journal, $63(4), 617$.

Kearns, E. M., Betus, A. E., \& Lemieux, A. F. (2019). Why do some terrorist attacks receive more media attention than others? Justice Quarterly, 36(6), 985-1022.

Kunst, J. R., Tajamal, H., Ulleberg, P., \& Sam, D. L. (2012). Coping with Islamophobia: The effects of religious stigma on Muslim minorities' identity formation. International Journal of Intercultural Relations, 36(4), 518-532.

Leuprecht, C., \& Winn, C. (2011). What do Muslim Canadians want? The clash of interpretations and opinion research. The Macdonald-Laurier Institute.

Martinovic, B., \& Verkuyten, M. (2012). Host national and religious identification among Turkish Muslims in Western Europe: The role of ingroup norms, perceived discrimination and value incompatibility. European Journal of Social Psychology, 42(7), 893-903.

Nacos, B. L., \& Torres-Reyna, O. (2007). Fueling our fears: Stereotyping, media coverage, and public opinion of Muslim Americans. Rowman \& Littlefield.

Nesdale, D. (2002). Acculturation attitudes and the ethnic and host-country identification of immigrants. Journal of Applied Social Psychology, 32(7), 1488-1507.

Nesdale, D., \& Mak, A. S. (2000). Immigrant acculturation attitudes and host country identification. Journal of Community \& Applied Social Psychology, 10(6), 483-495.

NHS (2011). The Canada 2011 National Household Survey. http://www12.statcan.gc.ca/censusrecensement/index-eng.cfm

Ogan, C., Willnat, L., Pennington, R., \& Bashir, M. (2014). The rise of anti-Muslim prejudice: Media and Islamophobia in Europe and the United States. International Communication Gazette, 76(1), 27-46.

Ozcurumez, S. (2009). Immigrant associations in Canada: Included, accommodated, or excluded? Turkish Studies, 10(2), 195-215.

Pew Research Center (2007). Muslim Americans: Middle class and mostly mainstream. http://www.pewresearch.org/2007/05/22/muslim-americansmiddle-class-and-mostlymainstream

Phinney, J. S., Berry, J. W., Vedder, P., \& Liebkind, K. (2006). The Acculturation Experience: Attituds, Identities and Behaviors of Immgrant Youth. In J. W. Berry, J. S. Phinney, D. L. Sam, \& P. Vedder (Eds.), Immigrant Youth in Cultural Transition: Acculturation, Identity, and Adaptation Across National Contexts. Mahwah, NJ: Lawrence Erlbaum Associates.

Robinson, L. (2009). Cultural identity and acculturation preferences among South Asian adolescents in Britain: An exploratory study. Children \& Society, 23(6), 442-454. 
Safdar, S., Calvez, S., \& Lewis, J. R. (2012). Multi-group analysis of the MIDA model: Acculturation of Indian and Russian immigrants to Canada. International Journal of Intercultural Relations, 36(2), 200-212.

Said, E. (1997). Covering Islam: How the Media and the Experts Determine How We See the Rest of the World. New York, NY: Vintage Books.

Saroglou, V., \& Mathijsen, F. (2007). Religion, multiple identities, and acculturation: A study of Muslim immigrants in Belgium. Archiv Für Religionspsychologie / Archive for the Psychology of Religion, 29(1), 177-198.

Sharify-Funk, M. (2009). Representing Canadian Muslims: Media, Muslim Advocacy Organizations, and Gender in the Ontario Shari'ah Debate. Global Media Journal: Canadian Edition, 2(2), 73-89.

Smith, J. L. (2009). Islam in America. In J. Cesari (Ed.), Muslims in the west after 9/11: Religion, politics and law. London; New York: Routledge.

Statistics Canada (2016). Census Profile, 2016 Census. https://www12.statcan.gc.ca/censusrecensement $/ 2016 / \mathrm{dp}$-pd/prof/details/page.cfm?Lang=E\&Geo1 $=$ PR\&Code1 $=01 \& G e 02=$ PR\&Code2 $=01 \&$ SearchText $=$ Canada $\&$ SearchType $=$ Begins $\&$ SearchPR $=01 \& B 1=$ Ethnic $\%$ 20origin \&TABID $=1 \&$ type $=0$

Te Lindert, A., Korzilius, H., Van de Vijver, F. J. R., Kroon, S., \& Arends-Tóth, J. (2008). Perceived discrimination and acculturation among Iranian refugees in the Netherlands. International Journal of Intercultural Relations, 32(6), 578-588.

U.S. Census Bureau (2017). American Community Survey. https://factfinder.census.gov/faces/tableservices/jsf/pages/productview.xhtml?pid=ACS_1 7_1YR_S0201 andprodType $=$ table

Verkuyten, M., \& Yildiz, A. A. (2007). National (dis)identification and ethnic and religious identity: A study among Turkish-Dutch Muslims. Personality and Social Psychology Bulletin, 33(10), 1448-1462.

Wayessea, B.S. (2017). We Are Not Alone: Conceptualizing People-Things Relationship in Oromo Community in North America. Journal of Ethnic and Cultural Studies, 4(1), 34-43. tp://dx.doi.org/10.29333/ejecs/60

Zaman, M. (2010). Bridging traditions: Madrasas and their internal critics. In A. Shryock (Ed.), Islamophobia/Islamophilia: Beyond the politics of enemy and friend. Bloomington, IN: Indiana University Press.

Manuscript received December 21, 2019

Final revision received March 10, 2020

Accepted March 19, 2020 